\title{
Smart Specialisation Priorities of Less Developed Regions. A Critical Evaluation
}

\author{
Petra Szávics ${ }^{(\bowtie)}(\mathbb{D})$ and József Benedek (D) \\ Babeș-Bolyai University, Cluj-Napoca, Romania \\ petra_szavics@yahoo.com
}

\begin{abstract}
This paper critically analysis the definition of smart specialisation priority areas of Romanian less developed regions, aiming to identify weaknesses in policy design that according to existing theories characterise such regions. Besides an empirical contribution to the literature, findings also have a practical relevance. They can be used by regions to redesign strategies in their preparation for the absorption of Cohesion Policy funds between 2021 and 2027. While in the definition of priority areas we could depict resemblance with the general practice presented in the literature, there are also shortcomings reported to the evaluation framework proposed in this paper based on official methodological and original theoretical aspects. These mainly refer to a less targeted approach within priorities, overlapping between priorities and horizontal character of vertically defined priorities. However, under these aspects, regional strategies present a high level of heterogeneity; thus, responsible institutions will need to invest different time and effort to revise policy documents.
\end{abstract}

Keywords: Smart specialisation - Less developed regions - Cohesion policy

\section{Introduction}

Smart specialisation strategies are policy interventions aiming to transform the economy by linking economic activities and market opportunities with research excellence and the potential of new technologies, taking into consideration local assets and challenges, as well as external sources of knowledge and local value chains [1-3]. Starting with the 2014-2020 programming period, such strategies have become ex-ante conditionality for declaring European Regional Development Fund (ERDF) expenditures in research and innovation under Thematic Objective (TO) 1. For the next financial exercise, strategies need to be revised in line with criteria under the enabling condition for Policy Objective (PO) 1 - A smarter Europe by promoting innovative and smart economic transformation.

A proper policy design contributes to the fulfilment of these criteria. Additionally, it is a pre-condition for the effective use of funds, maximising their efficiency [2], and ultimately their impact. Smart specialisation strategies, especially in terms of priorities and actions defined under the policy mix, are fed into Operational Programmes, setting the framework for financing operations. Priority selection in a vertical manner, reflecting a certain granularity level is one of the most important elements of a good 
policy design [2]. The impact of smart specialisation strategies is especially important in less developed regions, the main beneficiaries of Cohesion Policy funds. Implementation of these policies should contribute to the improvement of regional innovation performance and the reduction of development gaps. However, based on implementation experiences so far, the highest benefits of this approach are visible in developed regions [4]. Due to weaknesses observed in non-core regions, smart specialisation "may actually exacerbate regional imbalances and run counter to current EU cohesion policy" [5]. While there is a lot of reference throughout the literature regarding the problems such regions face [6-9], authors also note that each region presents particularities pending context, path dependencies and factors of structural, institutional and geographic character [10].

Against this background, the aim of our paper is to critically evaluate the definition of smart specialisation priority areas selected by Romanian less developed regions ${ }^{1}$, as one of the main indicators of proper policy design. Additionally, where appropriate, we propose to identify weaknesses in priority area definition. For this purpose the consistency of selected priorities will be evaluated against a set of criteria derived from the applicable methodological guidance and early theoretical aspects related to smart specialisation, which represented the most important information sources available at the time regional strategies have been elaborated. Additionally, some aspects observed at the level of general European Union practice in relation to priority area definition will also be used. Our paper will bring empirical evidence in order to enrich the existing literature on smart specialisation in less developed regions. Research on regional priority areas in Romania has not been performed yet and altogether the smart specialisation processes in Romanian development regions has not gained a lot of attention. There are two notable exemptions, i.e. a study on the smart specialisation process in the North East Development Region [11] and another one on the positive effects of the smart specialisation process on the development of regional innovation systems [12]. Findings can also have a practical relevance since Romanian regions with different levels of experience in the smart specialisation process [12] need to revise their strategies for the next programming period.

To proceed, we will start with a literature review on the most important aspects concerning smart specialisation, its link with Cohesion Policy and aspects related to priority area definition, including problems less developed regions face in this process. We will continue with the description of methodological aspects. The next chapter will be dedicated to the analysis of regional smart specialisation priorities based on the content of strategies, starting with a short overview of the smart specialisation experience in Romania, focusing on the regional level. We will resume with discussions and conclusions, presenting the limitations of our study and defining further areas of research.

\footnotetext{
${ }^{1}$ Romania has eight NUTSII development regions, out of which one developed (Bucharest-Ilfov) and seven less developed (West, Center, North West, North East, South West, South Muntenia and South West Oltenia). Five of the latter are also considered low income, thus lagging regions (North West, North East, South East, South Muntenia and South West Oltenia).
} 


\section{Smart Specialisation, Priorities and Cohesion Policy}

\subsection{Smart Specialisation and Cohesion Policy}

As a concept, smart specialisation refers to economic transformation, triggered by the agglomeration and spillover effects generated by new economic specialties $[1,2]$. Emphasis is on new economic activities that rely on existing productive assets, exploit new technologies and research capacities and result from a process of entrepreneurial discovery [2, 13]. Smart specialisation strategies are designed policy interventions, with the aim to facilitate such a transformative specialisation through vertical prioritisation in a limited number of economic areas [2].

Resonating with the reforms generated by the Barca report [14, 15], starting from 2014-2020, these "innovation driven development strategies" [16] have been set as exante conditionality for the use of ERDF under TO1 (Promoting research, development and innovation) and have gained a territorial dimension [2]. In the context of Cohesion Policy, such strategies are defined as integrated, place- and evidence-based economic transformation agendas, developed at the national/regional level, through a bottom-up process, in order to support research and technology driven economic development in selected priority areas, relying on local assets and capabilities, but also on external sources of knowledge and integration in global value chains [3]. To support strategy elaboration, the European Commission issued official methodological guidance and developed a dedicated platform [2].

Although major concerns have been raised regarding the efficacy of the concept, McCann [17] demonstrates that "smart specialisation emerges as being especially useful for many non-core regions as a way of prioritising policy initiatives and ensuring resource concentration". However, such regions face serious challenges linked to smart specialisation. Low capacity of institutions governing and participating in the process, weak innovation systems lacking cooperation culture and trust have negative effects on policy formulation [7-9, 18-21]. Success in the smart specialisation process is additionally hindered by the lack of technological diversification [21]. Dependence on declining industries, limited entrepreneurial and innovation capability especially affect the selection of priorities and the identification of new, transformative activities based on market opportunities [22]. While non-core regions face such challenges and they have less experience in such processes, they need to design and implement smart specialisation strategies based on an approach that presents weaknesses, since "it does not prescribe (...) specific tools for specific actions" [23] and it does not take into consideration the differences between different types of regions [22]. This may lead to a lack of understanding or misinterpretation of policy prioritisation and, in certain cases, to the selection of too many specialisation priorities and their too broad definition [24]. Inadequacies resulting from these bottlenecks represent "a significant challenge for Cohesion Policy" [25].

\subsection{Smart Specialisation Priorities}

According to the methodological guidance, a smart specialisation strategy should contain specialisation priorities, a policy mix with actions based on the analysis of 
socio-economic and research-development-innovation context, as well as input of stakeholders and monitoring and evaluation mechanisms [3]. An appropriate priority selection, which includes the results of entrepreneurial discovery processes, as a method of stakeholder involvement, is a criterion of good policy design [2]. Smart specialisation priorities can be defined as technologies or economic activities and should be limited in number [3]. Besides the vertical ones, horizontal priorities are recommended to be included, referring to the diffusion of novel technologies, organisational or social innovation. However, according to the same guidance, these can also be part of the policy mix [3].

Vertical priorities should reflect a middle level of granularity that is between the level of economic sectors and individual projects, pointing towards new, transformative activities matching or combining scientific or research, technological and economic strengths, market potential and opportunities [2]. This level of granularity reflects smart choices or niches, representing a precise expression of areas that would impact the economy most, such as: "ICT based innovation for active ageing", "wood-based solutions for eco-construction" [26], "nanotechnology applications for the pulp and paper industry" [27]. Furthermore, priorities should be about particularisation and they should be anchored in existing economic strengths or assets - identified at the level of clustered or correlated activities - taking into consideration emerging opportunities as identified by key actors possessing entrepreneurial and market knowledge [2].

Reflecting the experimental character of the policy, neither the theory, nor the methodological guidance offer detailed advice or a set of criteria to be used for priority selection. This is especially relevant in relation to the problems regions with less capacity and experience face when designing a strategy. Lack of selection criteria led to various approaches taken by regions in their priority area definition. A recent analysis of 39 regional and national strategies identified four dimensions used in different combination in order to define smart specialisation priorities, i.e. (1) sectors or value chains that reflect economic activities, (2) key enabling or general purpose technologies that activate transformation, (3) societal challenges that need to be overcome at European or the specific territorial level, (4) specific resources that can be exploited, like natural and cultural ones [28, 29]. However, the same authors acknowledge that matching all these dimensions within one smart specialisation area might be limitative and consider that combining at least two out of the four dimensions would be a proper approach [29]. Generally, priorities, defined through such a combination of different dimensions, are presented from one up to three levels [29].

The most important information on national and regional smart specialisation priorities is presented in a database hosted by the dedicated smart specialisation platform developed by the Joint Research Centre of the European Commission. The RIS3 database $^{2}$ contains two levels for each priority - the name of the priority and its description, including granularity level expressed through several niches - as well as policy objectives. As dimensions or areas linked to one specialisation priority there are

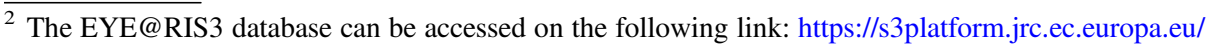
map.
} 
economic and scientific domains, using $\mathrm{NACE}^{3}$ rev. 2 and $\mathrm{NABS}^{4} 2007$ codes. Except for the name of priority area and its description, all other types of information can be selected from pre-set lists.

\section{Methodological Aspects}

To critically evaluate how priorities are defined in the smart specialisation strategies of Romanian less developed regions, we have developed a set of criteria based on methodological aspects from the official guidance [3] and interpreted them together with early theoretical aspects linked to smart specialisation $[1,2,13]$. Additionally, we also took into consideration the general practice at the EU level, deriving from existing studies [28, 29] and the architecture of the RIS3 database. Thus, from a methodological point of view, by priority area definition we understand the following aspects: (1) the vertical or horizontal character of priority areas, perceiving under (a) horizontal ones, priorities that refer to technology diffusion or aspects related to social, organisational innovation, and by (b) vertical ones, priorities that present a combination or intersection of at least the economic dimension with research or scientific strengths and potential use of key enabling or general purpose technologies; (2) the name of the priority area, which should reflect economic activities or technologies and (3) the granularity level of vertical priority areas in terms of niches that point towards new activities that are below the level of a sector and above the level of an individual project. Additionally, we have analysed if - in terms of economic area or activity ${ }^{5}$ - the economic dimension taken into consideration covers correlated or interlinked activities or areas. Moreover, we searched for other aspects taken into consideration during priority area definition, such as challenges, cultural or natural resources.

Our research based on the above-mentioned elements was carried out on the final Smart Specialisation Strategies of the Romanian less developed regions, approved by the Regional Development Councils, the governing body of Regional Development Agencies. These secondary documents were collected through desk-research from the official web-pages of the Agencies at the beginning of September 2019. The same strategies are in force at the moment and will undergo revision for the next programming period. We did not include in our research data from the RIS3 database, since, for the information presented, various sources, including unofficial ones (final strategy, draft strategy and/or other sources and studies) are referred by regions ${ }^{6}$. Only the chapters describing the selected smart specialisation priority areas and those

\footnotetext{
${ }^{3}$ Statistical Classification of Economic Activities in the European Community.

${ }^{4}$ Nomenclature for the Analysis and Comparison of Scientific Programmes and Budgets.

${ }^{5}$ While generally the literature refers to the economic dimension in terms of economic sector, we differentiate between economic areas in terms of 2 or 3 digit NACE divisions and economic activities in terms of 4 digit NACE divisions.

${ }^{6}$ Out of the seven less developed Romanian regions registered in the RIS3 database, two (Centre and South East) provide information based on the final strategy, two (North East and South West Oltenia) refer to other sources and studies besides the final strategy, one (North West) gives as a source the draft strategy and one (West) other study and source.
} 
describing the method of priority area selection were analysed. If there were separate documents containing additional information, they were also included in our research. This is the case of the Centre region, which has an annex to the strategy that contains a more detailed analysis of the specialisation priorities.

Based on the existing literature, our assumption is that priority selection might be less targeted in terms of number of priorities selected and their granularity level. Additionally, we expect to find differences between regions, pending their experience in smart specialisation processes. Two regions (North East and North West) have a higher degree of experience compared to all others [12].

\section{Smart Specialisation in Romanian Regions}

Romania, a Member State since 2007, is preparing for its third financial exercise. For the first two programming periods all Operational Programmes (OPs) have been developed centrally, relying on national strategies and policies. Currently, the Regional OP that has a separate budget for each of the eight NUTS II development regions represents a partial exception. Regional Development Strategies were also prepared by Regional Development Agencies (RDAs) for this programme. RDAs are organised as non-governmental organisations at the level of the NUTS II regions, out of which seven are less developed (West, North West, Centre, North East, South East, South Muntenia and South West Oltenia) and one - Bucharest-Ilfov - developed. These Agencies are the only regional level organisations that have tasks connected to strategic planning, but they are not officially responsible for research-developmentinnovation policies $[12,30]$. They also act as Intermediate Body for Regional OP, managed centrally by the responsible line ministry.

In order to substantiate interventions for TO1, selected for the Regional and Competitiveness OPs 2014-2020, Romania has elaborated and submitted as ex-ante conditionality the National Research-Development-Innovation Strategy 2014-2020. The document represented a partial fulfilment of the conditionality ${ }^{7}$. In parallel, even if not linked to the programming process, by 2014, some RDAs voluntarily developed Smart Specialisation Strategies [11, 12]. This was the case of the North East, West and Centre regions. By 2016, the strategies of South Muntenia and South West Oltenia were also finalised and North West started the process. In early 2016, two regions, namely North West and North East, were selected to receive support from the Joint Research Centre of the European Commission [12]. The pilot project "RIS3 support for lagging regions" was finalized in mid-2018, resulting in the revision of the strategy in the North East region and the elaboration of the strategy in the North West region. At the moment, these two regions are the most experienced in smart specialisation [12].

In March, 2016, the ROP 2014-2020 was amended, introducing the necessity to elaborate Framework Documents (Concept Notes) for Regional Smart Specialisation, to fundament the implementation of Priority Axes 1, financing technology transfer in

\footnotetext{
${ }^{7}$ Further information is to be found in the Partnership Agreement of Romania approved by the European Commission on August 14, 2014. Section 2.3. https://www.fonduri-ue.ro/acordparteneriat\#varianta-\%C3\%AEn-englez\%C4\%83.
} 
less developed regions. This amendment was also linked to the fulfilment of the ex-ante conditionality $[11,12]$. The Concept Notes were elaborated based on a methodology issued by the Regional OP Managing Authority, following the official EC guidelines and proposing general criteria for priority selection [31]. Thus, by 2018, all regions elaborated the Framework Document, including South East and updated or finalised their strategies. The West, South Muntenia and South West Oltenia Development Regions were exceptions, not performing an update of their existing policy document. For the next programming period, decentralized Regional OPs are proposed and RDAs need to revise strategies to meet the fulfilment criteria under PO1.

\section{Smart Specialisation Priorities of Romanian Less Developed Regions}

All seven strategies analysed have a chapter referring to the methodological aspects taken into consideration for the definition of priority areas. Generally, regions started with the analysis of economic potential in terms of critical mass, competitive and comparative advantages based on indicators, such as number of companies, number of employees, turnover, productivity, exports, and clusters. Such indicators were looked at on the level of economic areas or the level of interlinked, complementary economic activities. Only the North West region gives a clear definition of such activities, in terms of clusters of correlated industries, according to the definition of Cluster Observatory. As a second step, RDAs took into consideration the research-development dimension in terms of infrastructure, patents and licences, $R \& D$ projects and in some cases publications. Results of economic and scientific or research specialisation resulting from the first two steps were completed by an analysis of technological specialisation only in the case of the South Muntenia region and with the potential of using new technologies in the North West region. Additionally, all regions mention correlation with other assets (such as labour force, education) and/or dimensions (natural resources, societal challenges). The North West region also included global and European development tendencies. Potential priority areas resulting from the analysis were tested and validated in entrepreneurial discovery processes and modified according to their outcomes. In the case of the South East and South West Oltenia regions, these were preceded by gathering input from key stakeholders through interviews and questionnaires.

Most regions identified 6 smart specialisation priority areas, except for South East and Centre, which selected 7, respectively 9 priorities. In most cases regions defined only vertical priorities, except for the North West region defining "ICT" and the South Muntenia region selecting "High Tech Industry" as both a vertical and horizontal priority area, and South West Oltenia defining "ICT" and "Eco-technologies" as horizontal areas 8 . These horizontal priorities refer to the diffusion of general purpose

\footnotetext{
${ }^{8}$ The South East region mentions five additional horizontal priorities, including the diffusion of key enabling and information and communication technologies, besides those that refer to support RDI or cluster development. Since based on the strategy these can also be interpreted as being part of the policy mix, they were left out from the analysis. In the case of the North East region the priorities defined as horizontal ones are clearly part of the policy mix.
} 
technologies or other groups of technologies that also include key enabling ones, in all or most vertical areas. Regarding vertical priorities, two regions - West and Centre named them strictly in terms of economic activities, while other two - North West and South East - have priorities with names referring to both economic activities and technologies or groups of technologies. Besides reference to economic activities and technologies, South West Oltenia, South Muntenia and North East also use other name categories like "Bio-economy", "Smart localities", or "Energy-environment".

Priorities have an economic dimension in all seven strategies. In terms of four digit NACE codes, clear reference is only made in the strategies of the West, North West and Centre regions. In all other cases the economic area targeted can be deducted from the name and/or the description of the priority or the niches proposed. Generally, priorities are linked to areas of economic activities in terms of two or three digit NACE division, or groups of correlated economic areas or activities, but there are some exceptions. For example, under "Industrial engineering and transport", the South West Oltenia region included automotive, electrical, railway, rolling stock industries, constructions, as well as chemical and metallurgical industries. North West, under "New materials" refers to furniture, paper, plastic and packaging industries, as well as to metal working technologies. Full reference to corresponding research or scientific domains and technologies is to be found only in the case of the North West region, while South Muntenia emphasises corresponding technologies. The North East region highlighted corresponding research fields for all smart specialisation priority areas. As for the South West Oltenia region, only one priority has a declared research dimension. Two out of six priority areas have a rather weak research or technological dimension in the strategy of the West region, while one priority has both. However, in most cases, when no clear reference is made, a link between the targeted economic areas or activities and corresponding research areas and/or technological domains can be deducted from the name of the area and/or the proposed niches. The strategy of the Centre region presents a particular case, since several cross-cutting themes were defined in relation to the vertical priority areas. In some cases these indicate technologies and in all cases they refer to economic systems (circular economy) and/or principles (sustainable economy, energy efficiency). Such principles are referred to in general, at least at the level of objectives, in many of the strategies analysed. Other dimensions taken into consideration by all regions in relation to at least some of the priority areas refer to natural and cultural resources, societal or economic challenges.

The mid-grained granularity level or niches are missing from the strategy of the Centre region, from two priorities of the South East region, and are very limitedly referred to by the West region. In other cases there are generally several, i.e. two to fourteen niches that are listed under each specialisation priority. Except for North West, there is a certain overlap between the niches under the priorities that are defined vertically and those that are defined horizontally, or between those defined in economic and technological terms, or using other types of names. For example, in the case of the South West Oltenia region, new technologies in agriculture appear both under "Ecotechnologies" and under "Agriculture and food industry". In the strategy of the South Muntenia region, fertilizers as a niche appear under "Agriculture and food industry", as well as under "Bio-economy". Additionally, while advanced production technologies appear under the "High-tech industry" priority, intelligent production equipment is 
listed under "Construction of vehicles, component and equipment". Sustainable development of crops and new plants resistant to climate change, as well as new technologies in agro-food and precision agriculture are overlapping niches between "Agro-food" and "Energy-environment" priorities in the strategy of the North East region. Based on the proposed niches, in the case of the West region "ICT" rather represents a horizontal priority while "ICT, High-tech and advanced materials" represents both a vertical and a horizontal priority in the case of the South East region. The niches under these smart specialisation priorities refer to the diffusion of technologies in other vertical priority areas.

\section{Discussion}

In the seven regional smart specialisation strategies analysed, there were 6 to 9 priorities named in economic, technological, or other, more general terms. Priorities are mostly vertically designed. Only two regions assign both a vertical and horizontal character to some of their technologically named priorities and one region defines two solely horizontal priorities. Nevertheless, based on niches or granularity level, at least one of the vertical priorities chosen by three other regions has a horizontal character.

In terms of economic activities at the level of 4 digits NACE codes, the economic dimension of priorities can be clearly identified in three strategies. In all other cases reference to this dimension is weak, however information can be deducted. In most cases this dimension covers interlinked activities, except for one priority of North West and South East that encompasses several types of economic activities without a clear link between them. Reference to the scientific, research, or technological dimension of priorities is only made in the strategy of the North West region. North East focuses on the research dimension and South Muntenia on the technology dimension. In all other cases, such dimensions can only be deducted from the name of the priority area or niches, if defined. Granularity level or niches are almost or completely missing from the strategies of the West and Centre regions, while in all other cases several such niches are defined. Except for the North West region, there are overlaps between niches defined under different priority areas.

The main bottlenecks identified can be grouped under two aspects. One is the vertical definition of smart specialisation priorities, taking into consideration relevant dimensions and the other one is the targeted approach. Regarding the first aspect, we can mention the horizontal character of vertically defined areas, in some cases interlinked with a less proper naming of priorities, as well as overlaps between niches proposed under different priorities within one strategy. As for the second aspect, we can mention the rather big number of priorities, the lack of granularity level in some cases, or the multitude of niches identified under a priority area, as well as reference to several, not clearly interlinked economic areas or activities within one priority.

Although most of the smart specialisation priorities lack correspondence with the three dimensions taken into consideration in our methodology - economic, research or scientific and technological - a resemblance with the practice of other European regions can be observed, as presented by Gianelle, Guzzo \& Miezkowski [29]. Romanian less developed regions clearly link their priorities to at least an economic and a research or 
technological dimension, in many cases adding aspects linked to natural, cultural resources, societal or economic challenges, economic trends and principles.

Despite the apparently similar methodological approach taken by regions, outcomes in terms of priority definition and their granularity level differs from one strategy to another. While we have expected to find such differences based on the degree of experience regions have linked to smart specialisation as related by Ranga [12], strategies show a greater heterogeneity within the groups with more (North West and North East) and less experience (West, Centre, South East, South Muntenia and South West Oltenia). If we were to set up a hierarchy from the point of view of the quality of priority area definition, the North West region would have the fewest problems, followed by the North East and South Muntenia regions, than by South East and South West Oltenia, and finally by the Centre and West regions (Table 1). From a practical point of view, this means that redesigning strategies and priority areas will imply different effort and time invested by each region. When there are several niches under one priority, revision will be easier and will need to focus on selecting niches that could lead to new activities, triggering economic transformation as proposed by Foray [2]. When there are also overlaps between niches and thus between priority areas or niches lack completely, revision will imply a re-definition of all priorities.

Table 1. Synthetic presentation of main findings

\begin{tabular}{l|l}
\hline Specialisation priorities & Main findings \\
\hline Smart Specialisation Strategy of West Region (2016) \\
\hline \begin{tabular}{l|l} 
automotive components, textiles, ICT, agro- \\
food, constructions, tourism
\end{tabular} & $\begin{array}{l}\text { strong economic dimension of priorities; } \\
\text { niches are generally missing; ICT, a vertical } \\
\text { area, has a horizontal character }\end{array}$ \\
\hline
\end{tabular}

Smart Specialisation Strategy of North West Region (2018)

agro-food, cosmetics \& food supplements, $\quad$ priorities reflect all three dimensions; 2 to 12

health, new materials, advanced production niches under priorities; ICT is both a vertical technologies, ICT

and a horizontal priority

Smart Specialisation Strategy of Centre Region (2017)

automotive \& mechatronics, aerospace

industry, agro-food, textiles \& leather,

strong economic dimension of priorities; no

sustainable built environment, forestry \&

niches have been identified (accent on cross-

woodworking \& furniture, IT \& creative

cutting themes)

industries, health \& pharmaceuticals,

wellness tourism

Smart Specialisation Strategy of South West Oltenia Region (2016)

industrial engineering \& transport,

sustainable energy \& environment, basic \&

experimental innovative medicine,

agriculture \& agro-food, tourism \& cultural

identity, ICT, eco-technologies

mainly economic dimension of priorities; 2

to 12 niches under priorities, in some cases

presenting overlaps; ICT and eco-

technologies are defined as horizontal priorities 
Table 1. (continued)

\begin{tabular}{|c|c|}
\hline Specialisation priorities & Main findings \\
\hline \multicolumn{2}{|c|}{ Smart Specialisation Strategy of South Muntenia Region (2015) } \\
\hline $\begin{array}{l}\text { construction of vehicles, components \& } \\
\text { equipment, agriculture \& food industry, bio- } \\
\text { economy, tourism \& cultural identity, smart } \\
\text { localities, high tech industry }\end{array}$ & $\begin{array}{l}\text { strong technological dimension of priorities; } \\
5 \text { to } 9 \text { niches under priorities, in some cases } \\
\text { presenting overlaps; high-tech industry, a } \\
\text { vertical area, has a horizontal character }\end{array}$ \\
\hline \multicolumn{2}{|c|}{ Smart Specialisation Strategy of North East Region (2017) } \\
\hline $\begin{array}{l}\text { agro-food, bio-technologies, textiles \& new } \\
\text { materials, ICT, energy-environment, health } \\
\& \text { tourism }\end{array}$ & $\begin{array}{l}\text { strong research-scientific dimension of } \\
\text { priorities; } 5 \text { to } 14 \text { niches under priorities, in } \\
\text { some cases presenting overlaps }\end{array}$ \\
\hline \multicolumn{2}{|c|}{ Smart Specialisation Strategy of South East Region (2017) } \\
\hline $\begin{array}{l}\text { naval engineering \& transportation, clothing } \\
\text { industry, agro-food \& fisheries, bio- } \\
\text { technologies, eco-technologies, tourism, } \\
\text { ICT/high-tech \& advanced materials }\end{array}$ & $\begin{array}{l}\text { priorities only have a rather weak economic } \\
\text { dimension; } 2 \text { to } 10 \text { niches under each } \\
\text { priority; ICT, high tech and advanced } \\
\text { materials, defined vertically, has a horizontal } \\
\text { character }\end{array}$ \\
\hline
\end{tabular}

\section{Conclusions}

The aim of this paper was to critically analyse the smart specialisation priorities of Romanian less developed regions as indicators of proper policy design, based on a set of criteria derived from the existing methodological and early theoretical aspects concerning smart specialisation and taking into consideration the general EU level practice. Analysis was performed on regional level strategic documents developed during the 2014-2020 programming period by Romanian less developed regions. Empirical findings may contribute to enriching literature on smart specialisation in less developed regions, shedding light on problems faced by non-core regions in policy design. Last but not least, our aim was to point out some concrete aspects that need to be overcome by regions when redrafting strategies for the next programming period.

Romanian less developed regions present heterogeneity in their priority area definition in terms of a) dimensions used, i.e. economic, research or science and technological; b) vertical character of vertically defined areas and c) targeted character of approach, i.e. proper definition of niches or granularity level and limited number of economic activities or areas considered. The main shortcomings that can be considered as indicators of weaker policy design refer to the definition of several priorities and many niches within one priority or lack of such niches. Additionally, there are overlaps between niches corresponding to different priorities, as well as a lack of clear separation between vertical and horizontal priority areas. However, it must be acknowledged that, priority definition mainly follows the general approach taken by other European regions, which means that at least two dimensions are taken into account in the process of defining priorities. Romanian regions combine the economic dimension with a technological or a research-scientific dimension, or with other aspects such as resources, principles, challenges. 
A revision of the strategies for the next programming period in order to reach a more targeted approach in priority area definition and thus a greater impact of funds spent will require different levels of effort from each region, pending on the number of weaknesses identified. As a first step, regions might consider matching the three dimensions proposed in this paper with each priority area. Results should than be further tested with stakeholders to reach the appropriate granularity level. For this purpose, some regions, especially those that make reference to other sources and studies in the RIS3 database of the smart specialisation platform, might already possess additional data.

Besides these practical aspects, our analysis and results may contribute to the existing literature, by pointing out some specific problems linked to strategy design in Romanian less developed regions. For a more accurate picture, research should be expanded to cover the exact reasons of the weaknesses identified, with emphasis on the capacity of institutions managing the process and that of stakeholders involved in it. Results of systematically conducted analysis in other areas concerning the use of Cohesion Policy funds may also be considered, such as the impact of bad policy design on the success of the National Growth Pole Strategy [32, 33]. Additionally, the results of entrepreneurial discovery processes should be fed in. Not covering these aspects represents one of the main limitations of this study, but at the same time it sets further research objectives.

Acknowledgement. Elaboration and publication of this paper have been mainly supported by the Romanian Ministry of Research and Innovation, under project number PN-III-P4-ID-PCCF2016-00084, financed from the National Plan for RDI 2015-2020 (PNCDI III), implemented by the Executive Unit for Financing Higher Education, Research, Development and Innovation National University Research Council.

\section{References}

1. Foray, D., David, P.A., Hall, B.H.: Smart specialization. From academic idea to political instrument, the surprising career of a concept and the difficulties involved in its implementation. MTEI-Working Paper 001 (2009). https://pdfs.semanticscholar.org/29ad/ 6773ef30f362d7d3937c483003d974bc91c5.pdf. Accessed 15 Jan 2020

2. Foray, D.: Smart Specialisation. Opportunities and Challenges for Regional Innovation Policy. Routledge, London (2015)

3. European Union: Guide to Research and Innovation Strategies for Smart Specialisations (RIS 3). European Commission, Brussels (2012)

4. European Commission: Impact Assessment Accompanying the document - Proposals for a Regulation of the European Parliament and of the Council on the European Regional Development Fund and on the Cohesion Fund on a mechanism to resolve legal and administrative obstacles in a cross-border context on specific provisions for the European territorial cooperation goal (Interreg) supported by the European Regional Development Fund and external financing instruments. SWD 282. https://ec.europa.eu/transparency/regdoc/rep/ 10102/2018/EN/SWD-2018-282-F1-EN-MAIN-PART-1.PDF. Accessed 20 Jan 2020

5. Barzotto, M., Corradini, C., Fai, F.M., Labory, S., Tomlinson, R.: Executive summary. In: Barzotto M., Corradini C., Fai, F.M., Labory S., Tomlinson P.R. (eds.) Revitalising Lagging Regions: Smart Specialisation and Industry 4.0, p. 9. Taylor \& Francis, Oxon (2019) 
6. Blažek, J., et al.: Smart specialisation for regional innovation. Regions with less developed research and innovation systems. Reflection Paper. FP7 project with grant no. 320131 (2014). https://orca.cf.ac.uk/78219/1/Regions\%20with\%20Less\%20Developed\% 20Research\%20and\%20Innovation\%20Systems.pdf. Accessed 26 Aug 2019

7. McCann, P., Ortega-Argilés, R.: Smart specialisation: insights from the EU experience and implications for other economies. J. Reg. Res. 36, 279-293 (2016)

8. Tsipouri, L.J.: Fostering innovation in less-developed and low institutional capacity regions: Challenges and opportunities. Background paper for an OECD/EC Workshop on 22 June 2018 within the workshop series "Broadening innovation policy: New insights for regions and cities", Paris. https://www.oecd.org/cfe/regional-policy/Tsipouri(2018)FosteringInnovationIn LessDevelopedRegions.pdf. Accessed 26 Jan 2020

9. Trippl, M., Zukauskaite, E., Healy, A.: Shaping smart specialization: the role of placespecific factors in advanced, intermediate and less-developed European regions. Reg. Stud. (2019). https://doi.org/10.1080/00343404.2019.1582763

10. Blažek, J., et al.: Smart specialisation for regional innovation. Regions with less developed research and innovation systems. Research Working Paper. FP7 project with grant no. 320131 (2014). https://orca.cf.ac.uk/78216/1/Regions\%20less\%20developed.pdf. Accessed 26 Aug 2019

11. Healy, A.: Smart specialization in a centralized state: strengthening the regional contribution in North East Romania. Eur. Plann. Stud. 24(8), 1527-1543 (2016). https://doi.org/10.1080/ 09654313.2016.1184233

12. Ranga, M.: Smart specialization as a strategy to develop early stage regional innovation systems. Eur. Plann. Stud. 26(11), 2125-2146 (2018). https://doi.org/10.1080/09654313. 2018.1530149

13. Foray, D.: From smart specialisation to smart specialisation policy. Eur. J. Innov. Manage. 17(4), 492-507 (2014). https://doi.org/10.1108/EJIM-09-2014-0096

14. McCann, P., Ortega-Argilés, R.: Smart specialisation, regional growth and applications to EU cohesion policy. Reg. Stud. 49(8), 1291-1302 (2015). https://doi.org/10.1080/00343404. 2013.799769

15. McCann, P.: The Regional and Urban Policy of the European Union. Edward Elgar Publishing, Cheltenham, UK, Northamton, MA, USA (2015)

16. European Union: Regional policy for smart growth in Europe 2020, p. 7. EU Publications Office, Brussels (2011)

17. McCann, P.: The Regional and Urban Policy of the European Union, p. 160. Edward Elgar Publishing, Cheltenham, UK, Northamton, MA, USA (2015)

18. Badescu, G., Uslaner, E.: Social Capital and the Transition to Democracy. Routledge, London (2004)

19. Koczinszky, G., Benedek, J.: Contributions to the impact assessment of network cooperation among social enterprises. Theor. Methodol. Pract. Club Econ. Miskolc 15(2), 23-28 (2019)

20. Rodrígez-Pose, A., Ketterer, T.: Institutional change and the development of lagging regions in Europe. Reg. Stud. 54(7), 974-986 (2020). https://doi.org/10.1080/00343404.2019. 1608356

21. McCann, P., Ortega-Argilés, R.: Perspectives on smart specialisation policies in lagging regions. In: Barzotto, M., Corradini, C., Fai, F.M., Labory, S., Tomlinson, P.R. (eds.) Revitalising Lagging Regions: Smart Specialisation and Industry 4.0, pp. 17-27. Taylor \& Francis, Oxon (2019)

22. Barzotto, M., Corradini, C., Fai, F.M., Labory, S., Tomlinson, R.: An extra-regional collaborative approach to smart specialisation. In: Barzotto, M., Corradini, C., Fai, F.M., Labory, S., Tomlinson, P.R. (eds.) Revitalising Lagging Regions: Smart Specialisation and Industry 4.0, pp. 29-41. Taylor \& Francis, Oxon (2019) 
23. McCann, P., Ortega-Argilés, R.: Perspectives on smart specialisation policies in lagging regions. In: Barzotto, M., Corradini, C., Fai, F.M., Labory, S., Tomlinson, P.R. (eds.) Revitalising Lagging Regions: Smart Specialisation and Industry 4.0, pp. 17-27, p. 19. Taylor \& Francis, Oxon (2019)

24. Potter, J., Lawton Smith, H.: Smart specialisation in Eastern Europe: insights from two lagging Polish regions. In: Barzotto, M., Corradini, C., Fai, F.M., Labory, S., Tomlinson, P. R. (eds.) Revitalising Lagging Regions: Smart Specialisation and Industry 4.0, pp. 43-53. Taylor \& Francis, Oxon (2019)

25. McCann, P., Ortega-Argilés, R.: Perspectives on smart specialisation policies in lagging regions. In: Barzotto, M., Corradini, C., Fai, F.M., Labory, S., Tomlinson, P.R. (eds.) Revitalising Lagging Regions: Smart Specialisation and Industry 4.0, pp. 17-27, p. 18. Taylor \& Francis, Oxon (2019)

26. European Union: Guide to Research and Innovation Strategies for Smart Specialisations (RIS 3), p. 52. European Commission, Brussels (2012)

27. Foray, D.: Smart Specialisation. Opportunities and Challenges for Regional Innovation Policy, p. 42. Routledge, London (2015)

28. Gianelle, C., Guzzo, F., Miesykowski, K.: Smart Specialisation at Work: Assessing Investment Priorities. JRC Technical Reports, JRC113433. European Commission, Seville (2018)

29. Gianelle, C., Guzzo, F., Miesykowski, K.: Smart specialisation: what gets lost in translation from concept to practice? Reg. Stud. (2019). https://doi.org/10.1080/00343404.2019. 1607970

30. Benedek, J., Török, I., Máthé, C.: Evidence-based designation of development regions in Romania. Reg. Stat. 8(1), 1-20 (2018). https://doi.org/10.15196/RS080105

31. MRDPA (Ministry of Regional Development and Public Administration). Methodology for the elaboration of the Framework Document for Smart Specialisation (2016). http://www.adrse.ro/ Documente/Planificare/DCR/Metodologie_realizarea_DCR.pdf. Accessed 04 Sep 2019

32. Benedek, J.: The role of urban growth poles in regional policy: the Romanian case. In: Calabró, F., Della Spina, L. (eds.) 2nd International Symposium on New Metropolitan Perspectives - Strategic Planning, Spatial Planning, Economic Programs and Decision Support Tools, Through the Implementation of Horizon/Europe 2020. ISTH2020. Reggio Calabria (Italy), 18-20 May 2016. Procedia-Social and Behavioural Sciences, vol. 223, pp. 1986, 285-290. Elsevier, Amsterdam (2016). https://doi.org/10.1016/j.sbspro.2016.05.368

33. Benedek, J., Varvari, Ș., Litan, C.: Chapter 8: urban growth pole policy and regional development: old wine in new bottles? In: Lang, T., Görmar, F. (eds.) Regional and Local Development in Times of Polarization. Re-Thinking Special Policies in Europe, pp. 173196. Palgrave/MacMillan, Basingstoke (2019). https://doi.org/10.1007/978-3-319-67277-9 
Open Access This chapter is licensed under the terms of the Creative Commons Attribution 4.0 International License (http://creativecommons.org/licenses/by/4.0/), which permits use, sharing, adaptation, distribution and reproduction in any medium or format, as long as you give appropriate credit to the original author(s) and the source, provide a link to the Creative Commons license and indicate if changes were made.

The images or other third party material in this chapter are included in the chapter's Creative Commons license, unless indicated otherwise in a credit line to the material. If material is not included in the chapter's Creative Commons license and your intended use is not permitted by statutory regulation or exceeds the permitted use, you will need to obtain permission directly from the copyright holder.

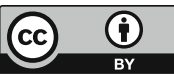

